Clin Chest Med. 2016 December ; 37(4): 633-646. doi:10.1016/j.ccm.2016.07.004.

\title{
Ventilator-Induced Lung Injury
}

\author{
Jeremy R. Beitler, MD, MPHa , Atul Malhotra, MDa, and B. Taylor Thompson, MD ${ }^{b}$ \\ aDivision of Pulmonary and Critical Care Medicine, University of California, San Diego, San \\ Diego, CA \\ bDivision of Pulmonary and Critical Care Medicine, Massachusetts General Hospital, Boston, MA
}

\begin{abstract}
Keywords
ventilator-induced lung injury; acute lung injury; acute respiratory distress syndrome; mechanical ventilation; respiratory mechanics
\end{abstract}

\section{INTRODUCTION}

As with most medical and pharmacological interventions, mechanical ventilation must be titrated within a therapeutic window, providing the required life-sustaining support while minimizing unintended toxicity. The potential for mechanical ventilation to cause harm was first described in the mid- $18^{\text {th }}$ century. ${ }^{1,2}$ John Fothergill postulated mouth-to-mouth resuscitation may be preferable to mechanical ventilation because "the lungs of one man may bear, without injury, as great a force as those of another man can exert; which by the bellows cannot always be determined". ${ }^{1}$ Over 250 years later, ventilator-induced lung injury (VILI) was proven definitively to contribute to mortality in patients with acute respiratory distress syndrome (ARDS). ${ }^{3}$

Classically, four mechanisms of VILI have been described: barotrauma, volutrauma, atelectrauma, and biotrauma (Table 1). ${ }^{4}$ Recent recognition that heterogeneous regional mechanics, stress frequency, and pulmonary capillary stress failure may also contribute to VILI has inspired a renewed line of investigation toward personalizing lung-protective ventilation.

Corresponding Author: Jeremy R. Beitler, MD, MPH, University of California, San Diego, 200 West Arbor Drive, \#8409, San Diego, CA 92103, jbeitler@ucsd.edu.

Atul Malhotra, MD, University of California, San Diego, 9300 Campus Point Drive, \#7381, La Jolla, CA 92037, amalhotra@ucsd.edu B. Taylor Thompson, MD, Massachusetts General Hospital, 55 Fruit Street, Cox 201, Boston, MA 02114, tthompson1@partners.org

Publisher's Disclaimer: This is a PDF file of an unedited manuscript that has been accepted for publication. As a service to our customers we are providing this early version of the manuscript. The manuscript will undergo copyediting, typesetting, and review of the resulting proof before it is published in its final citable form. Please note that during the production process errors may be discovered which could affect the content, and all legal disclaimers that apply to the journal pertain.

DISCLOSURES

Conflicts of Interest: All authors report they have no potential conflicts of interest. 


\section{CLASSIC MECHANISMS OF VILI}

\section{Barotrauma and Volutrauma}

In 2000, the landmark ARDS Network trial demonstrated definitively that limiting tidal volume (6 vs. $12 \mathrm{~mL} / \mathrm{kg}$ predicted body weight [PBW]) and plateau airway pressure ( $\leq 30$ vs. $\leq 50 \mathrm{cmH}_{2} \mathrm{O}$ ) improves survival in patients with ARDS. ${ }^{3}$ This study and a small preceding pilot trial ${ }^{5}$ brought into clinical practice what had been suggested for decades by preclinical studies - that mechanical ventilatory support with high volumes and pressures can cause preventable morbidity and mortality in critically ill patients.

Lung Volume \& Transpulmonary Pressure-For much of the last thirty years, barotrauma (high inflation pressure-mediated lung injury) and volutrauma (overdistensionmediated lung injury) were viewed as distinct albeit related entities. In a classic study by Dreyfuss et al., ${ }^{6}$ rats were mechanically ventilated using one of three strategies: (1) high airway pressures and high tidal volumes; (2) high airway pressures and low tidal volumes; or (3) low airway pressures and high tidal volumes. The high-pressure low-volume strategy was achieved via thoracoabdominal strapping with rubber bands, decreasing chest wall compliance. Conversely, the low-pressure high-volume strategy was achieved via an iron lung (negative pressure ventilator). Animals supported with either high-volume strategy had markedly more severe lung injury compared to animals ventilated with the high-pressure low-volume strategy. Similar findings have been replicated in other animal models, ${ }^{7-9}$ leading to the misleading conclusion that volutrauma is more important than barotrauma. $4,6,10$

It is true that high airway pressure per se does not cause VILI, as these studies confirmed. Yet, the pertinent distending pressure of the lungs is not simply the airway pressure, but rather the transpulmonary pressure (airway minus pleural pressure), the difference between the pressure inside versus outside the lung (Fig. 1). ${ }^{11-13}$ Comparable transpulmonary pressures are achieved for a given lung volume regardless of whether airway pressure is positive (as during mechanical ventilation) or negative (as during normal spontaneous breathing).

Thus, lung volume and transpulmonary pressure are inherently related. In the Dreyfuss study, thoracoabdominal strapping in the high-[airway]-pressure low-volume group impeded chest wall excursion and thus assured both low lung volumes and low transpulmonary pressures. Conversely, in the low-[airway]-pressure high-volume group, iron lung negative pressure ventilation resulted in both high lung volumes and high transpulmonary pressures.

Failure to consider transpulmonary pressure in the mechanically ventilated patient can lead to miscalculating VILI risk. On one end, high airway pressures in morbid obesity in part may reflect transmitted high pleural pressures (i.e. low transpulmonary pressure) and not necessarily overdistension. ${ }^{14,15}$ At the other extreme, the critically ill ARDS patient with air hunger and forceful spontaneous inspiratory muscle effort may have low airway pressures but large pleural and transpulmonary pressure swings and resultant tidal volumes, predisposing to barotrauma/volutrauma. ${ }^{16}$ 
Tonically Held vs. Cyclic Volumes \& Pressures-The lungs appear to respond differently to high volumes and transpulmonary pressures depending on how they were achieved. In vitro models of alveolar type I and type II cells placed in a biaxial stretcher have demonstrated that cyclic strain (i.e. repeated, cyclic deformations) induce more cell death than a single, tonically held deformation of the same peak magnitude. ${ }^{17,18}$ For a given peak strain, decreasing cyclic strain reduced the amount of cell death.

Analogous findings have been observed in vivo with animal models of VILI. High tidal volumes, with associated large cyclic strain, cause lung injury. ${ }^{6,19,20}$ Yet, achieving the same peak strain with high PEEP and low tidal volumes, i.e. high end-expiratory lung volume and low cyclic strain, induces comparatively less lung injury. ${ }^{21-23}$ Existing human data similarly suggest that VILI risk for a given end-inspiratory pressure and volume during mechanical ventilation may depend on the relative contributions of PEEP (tonically held deformation, less injurious) versus tidal volume (cyclic deformations, more injurious). ${ }^{24-26}$ Translating these findings to clinical practice, if an upper limit on inspiratory pressure is exceeded, decreasing tidal volume rather than PEEP may afford additional lung protection.

Cellular Effects of Volutrauma \& Barotrauma-The classic schema of alveoli as balloon-like structures that stretch during tidal inflation may not fully represent alveolar micromechanics. During normal breathing, alveolar walls themselves appear also to "unfold," minimizing elastic stretch and cellular strain except when lung volumes approach total lung capacity. ${ }^{27-30}$ Deformation-related cell strain, when it does occur, induces rapid lipid trafficking to the plasma membrane, increasing cell surface area to prevent plasma membrane rupture and to repair the cell when stress failure does occur. ${ }^{31-33}$ When these cytoprotective mechanisms are exceeded, additional inflation translates directly into cell strain, producing cell detachment from the basement membrane, epithelial and endothelial cell junction breaks, intracapillary blebs, and alveolar and interstitial edema, the microscopic correlates of clinical lung injury. 6,34

\section{Atelectrauma}

In ARDS, surfactant dysfunction and weight of the edematous lung contribute to regional atelectasis. ${ }^{35,36}$ Cyclic opening and collapse of such atelectatic but recruitable lung units during tidal ventilation contribute to lung injury termed atelectrauma. ${ }^{36-38}$ For atelectatic alveoli, high shear stress is generated during recruitment at the interface between the air bolus and collapsed airway, causing mechanical injury (Fig. 2). ${ }^{39,40}$ For flooded alveoli, formation and destruction of foam bubbles at the gas-liquid interface of flooded alveoli contributes additional local interfacial stress that disrupts plasma membrane-cytoskeletal adhesions and leads to lung injury. ${ }^{41}$

Clinically, low tidal volume ventilation may minimize atelectrauma by maintaining low airway driving pressures, decreasing likelihood of exceeding the critical opening pressure of collapsed lung units. ${ }^{42}$ Additionally, PEEP set above the critical closing pressure of potentially collapsible lung units promotes sustained recruitment and may further prevent atelectrauma, ${ }^{5,26,43-46}$ though the optimal PEEP titration strategy remains to be defined. 


\section{Biotrauma}

Mechanical lung injury triggers an extensive biological response, including activation of a proinflammatory and pro-injurious cytokine cascade termed biotrauma. ${ }^{23,47-49}$ This cascade may promote injury even in lung regions not faced with significant mechanical insult. Perhaps more importantly, this proinflammatory response also promotes extrapulmonary organ injury, predisposing to multiorgan failure that carries increased risk of death. ${ }^{23,47-53}$

The epithelial surface area of each adult lung is estimated to be $700-900$ square feet, ${ }^{54}$ nearly the size of one-half of a tennis court. Thus, in the lung, biological responses that are comparatively small in magnitude on a cellular level can precipitate collectively a substantial release of pro-injurious mediators. Compounding this signal amplification, roughly the entire blood volume of the human adult passes through the pulmonary circulation every minute. Thus, proinflammatory and pro-injurious mediators produced by the lung, upon entering the circulation, are readily transported throughout the body where they affect previously uninvolved organs. More than a theoretical construct, human ARDS clinical trials have confirmed that lung-protective ventilation indeed attenuates systemic inflammation ${ }^{48,52}$ and extrapulmonary organ system failures (e.g. cardiovascular, renal, hepatic), ${ }^{3,53}$ helping to account for their associated survival benefit.

\section{REGIONAL MECHANICS}

A seminal discovery shaping our current understanding of VILI occurred in the mid-1980s, when the first CT scans of patients with ARDS revealed strikingly heterogeneous lung parenchyma. In the classic CT for ARDS, patchy areas of well-aerated lung and poorly aerated lung are found in the ventral regions, with dense dependent atelectasis distributed in the dorsal posterior regions of the supine patient. ${ }^{55-57}$ These radiographic discoveries suggest that (1) regional mechanics may vary throughout the ARDS lung; and (2) the total volume of aerated lung available to ventilate is reduced in size in patients with ARDS.

\section{Lung inhomogeneity and shear strain}

Differences in regional mechanics throughout the ARDS lung induce additional mechanical stresses that predispose to VILI. Neighboring alveoli are mechanically interdependent. ${ }^{11,58}$ Collapse or flooding of one lung unit necessarily induces deformation of adjacent units as the interalveolar septum stretches inward toward the atelectatic or flooded unit. As a result, the adjacent air-filled alveolus experiences additional shear strain as it inflates nonuniformly (Fig. 3). Isolated, perfused animal lung models, wherein single-alveolus pulmonary edema is induced by micropuncture, have visualized this process with confocal microscopy. ${ }^{58}$ In vivo animal models using PET have found $\left[{ }^{18} \mathrm{~F}\right]$ fluoro-2-deoxy-D-glucose uptake, indicating local neutrophilic activation, is increased in areas of high regional strain. ${ }^{59}$ Initial human studies using PET CT similarly have confirmed lung inflammation to be heterogeneous in patients with ARDS, likely in part due to differences in regional strain. ${ }^{60,61}$ These findings suggest a causal linkage to the association between parenchymal inhomogeneity and mortality observed in patients with ARDS. ${ }^{62}$ 
Both PEEP and prone positioning may reduce VILI in severe ARDS in part by improving lung homogeneity, yielding more uniform strain distribution. ${ }^{63-67}$ Adequate PEEP minimizes small airways collapse, promoting sustained recruitment that improves lung homogeneity and increases total aerated lung volume available for tidal ventilation. PEEP may also redistribute edema fluid from the flooded alveolus into the interstitial space, decreasing shunt fraction while perhaps promoting more uniform interdependent alveolar mechanics. ${ }^{68,69}$ PEEP appears to have mixed effects on pulmonary lymphatic flow, involved in clearance of extravascular lung water, depending on hemodynamic management and lung compliance ${ }^{70-72}$ PEEP has been shown in most ARDS animal models to protect against VILI. ${ }^{6,22,37,49}$ Human studies with ARDS have yet to identify the optimal PEEP titration strategy, ${ }^{43-45}$ though in general higher PEEP may be warranted in patients with more severe ARDS. ${ }^{73}$ Most major clinical trials to date have adjusted PEEP based on oxygenation requirements using an arbitrary $\mathrm{PEEP}_{-\mathrm{FiO}}$ titration table. $^{3,43,44,63,74-76}$ Yet, a PEEP titration strategy that seeks not only to maintain oxygenation but also to reduce regional strain may afford additional lung protection in patients with ARDS. Several such strategies have been tested in small clinical studies, ${ }^{5,46,77-80}$ but none to date in a large multi-center trial adequately powered for patient-centered outcomes.

Prone positioning similarly appears to improve lung homogeneity. In the normal lung, alveolar size decreases from ventral to dorsal regions due to gravity and shape-matching of the lung and thoracic cavity. ${ }^{35}$ Increased mass of the edematous ARDS lung generates a superimposed pressure on gravity-dependent lung regions, ${ }^{35}$ leading to dense atelectasis of the dorsal lung regions with relative sparing of more ventral regions. When the patient is repositioned prone, shape matching again favors decreased alveolar size from ventral to dorsal regions, but the gravitational effect (non-trivial from edema weight in ARDS) now favors expansion of dorsal regions. ${ }^{81}$ The net effect, as evidenced on CT, appears to be more homogeneous aeration throughout the lung, ${ }^{66,81}$ likely promoting more uniform strain distribution and thus lung protection. Indeed, the recent PROSEVA multicenter randomized trial found that proning patients with early severe ARDS for at least 16 hours/day improved survival compared to semirecumbent supine positioning_despite management with identical lung-protective mechanical ventilation strategies. ${ }^{63}$ While the effect size in PROSEVA may overestimate that of proning-due to more frequent use of neuromuscular blockade in the prone arm (which may afford additional lung protection ${ }^{76}$ ) and greater baseline vasopressor requirements in the supine arm-we believe proning does afford added lung protection in select patients with severe ARDS.

Although PEEP and proning share related physiological mechanisms, a mechanics-based PEEP titration strategy has not been studied adequately in a major trial of prone positioning. At least one physiological human study suggests concomitant proning and comparatively higher PEEP may further improve lung homogeneity relative to either strategy in isolation. ${ }^{82}$ However, the extent to which a mechanics-based PEEP titration strategy affords additional clinical benefit during prone positioning, or vice versa, is unknown. ${ }^{64}$ 


\section{The ARDS "Baby Lung”}

In patients with ARDS, the weight of superimposed edematous lung tissue, coupled with surfactant dysfunction, contribute to dense atelectasis of dependent lung regions. ${ }^{35,38,83}$ As a result, the volume of aerated lung available for gas exchange and mechanical insufflation is reduced, a concept termed the ARDS baby lung (Fig. 4). ${ }^{84}$ The baby lung is not a fixed anatomical structure, as evidenced by redistribution of dependent atelectasis to ventral regions with prone positioning. ${ }^{81,85}$ Nor does aerated lung equate to normal lung, as evidenced by enhanced $\left[{ }^{18} \mathrm{~F}\right]$ fluoro-2-deoxy-D-glucose uptake signaling active inflammation in aerated regions. ${ }^{86}$

Baby lung inspiratory capacity predicts end-inspiratory lung stress during tidal ventilation, ${ }^{25}$ suggesting low tidal volumes may be effective in ARDS in part because the functional lung volume itself is reduced. Indeed, the original ARDS Network trial authors reasoned that lower tidal volumes may be required to prevent regional overdistension in ARDS in part because the aerated lung volume is reduced. ${ }^{3}$ In vivo preclinical models using diffusionweighted hyperpolarized gas MRI have found the aerated baby lung may experience regional overdistension. ${ }^{87,88}$ An ideal lung-protective strategy might scale tidal volumes to functional baby lung size rather than predicted healthy lung size (i.e. $\mathrm{mL} / \mathrm{kg}$ PBW). Such strategies have been explored in physiological studies ${ }^{25,89,90}$ but have yet to be tested in prospective clinical trials powered for patient-centered outcomes.

\section{STRESS FREQUENCY \& PERMISSIVE HYPERCAPNIA}

Both the magnitude and frequency of peak alveolar stretch likely to contribute to VILI. ${ }^{91}$ Preclinical studies have found that, for a given magnitude of lung stretch, increasing the stretch frequency also worsens lung injury. ${ }^{17,91-93}$ In human studies, infrequent highvolume breaths, such as occasional recruitment maneuvers or sigh breaths, do not appear to cause clinically significant lung injury ${ }^{94}$ and may even afford transient lung protection. ${ }^{95-98}$ At the other extreme, delivery of high tidal volumes with every breath clearly worsens VILI and mortality in patients with ARDS. ${ }^{3,5}$ We speculate the dose-response curve for the relationship between frequency of high-volume breaths and VILI may be J-shaped. Occasional high-volume breaths, such as sighs, may be protective by preventing derecruitment, ${ }^{96}$ increasing lung homogeneity, ${ }^{97}$ and increasing baby lung size (maintained if PEEP exceeds small airways closing pressure) ${ }^{25}$ However, frequent high tidal volumes cause VILI in at-risk patients.

The precise role for limiting stress frequency remains to be determined. Maintaining a low tidal volume strategy while also limiting stress frequency—by limiting respiratory rate—will result in hypercapnic acidosis, a strategy termed permissive hypercapnia. ${ }^{5,99}$ This approach was shown in a small clinical trial to improve survival compared to a high tidal volume strategy. ${ }^{5}$ However, permissive hypercapnia was not evaluated in the ARDS Network trial of high vs low tidal volumes, ${ }^{3}$ which instead advised a high respiratory rate to achieve near eucapnia and normal $\mathrm{pH}$. The high-respiratory rate strategy of the ARDS Network likely requires less sedation during low tidal volume ventilation than a permissive hypercapnia strategy. Because hypercapnic acidemia heightens respiratory drive, deep sedation or 
neuromuscular blockade may be required to reinforce lung-protective ventilation and minimize patient-ventilator dyssynchrony during permissive hypercapnia.

Hypercapnia also has several biological effects of unclear clinical consequence. In preclinical VILI models, hypercapnic acidosis impaired alveolar cell migration ${ }^{100}$ and plasma membrane repair ${ }^{101}$ following mechanical injury, the latter in a $\mathrm{pH}$-dependent fashion. ${ }^{101}$ Hypercapnia, independent of $\mathrm{pH}$, also may impair alveolar edema fluid clearance by promoting endocytosis of plasma membrane $\mathrm{Na}^{+}-\mathrm{K}^{+}$-ATPase channels involved in maintaining the $\mathrm{Na}^{+}$gradient that water follows. ${ }^{102}$ Hypercapnia attenuates TNF-a, IL-1, IL-6, and IL-8 cytokine production, oxygen free radical formation, and NF- $\kappa B$ activation, ${ }^{103-107}$ potentially limiting the cascading effects of biotrauma on pulmonary and extra-pulmonary organ failure. In vivo models of VILI, ${ }^{108,109}$ bacterial pneumonia, ${ }^{110}$ and abdominal sepsis ${ }^{111}$ have demonstrated that hypercapnic acidosis, achieved via inspired $\mathrm{CO}_{2}$, attenuates lung injury. Different experimental preparations have yielded conflicting results on the effects of hypercapnia in pulmonary infection, ${ }^{112}$ highlighting the need for further translational research and ultimately clinical studies.

\section{CAPILLARY STRESS FAILURE}

In addition to alveolar epithelial injury, capillary endothelial stress failure likely contributes to VILI. Enhanced regional pulmonary blood flow, such as occurs from hypercapnic adrenergic tone or attempted ventilation-perfusion matching, increases capillary wall stress. ${ }^{113}$ Multiple preclinical models have found that increasing pulmonary blood flow worsens lung injury. ${ }^{113-116}$ Dynamic shear forces from blood flow appear to play a central role, as achieving high capillary pressure by raising left atrial pressure statically does not produce comparable lung injury. ${ }^{115}$ Importantly, increasing pulmonary blood flow may lead to lung injury that otherwise would not occur during moderate tidal overdistension. ${ }^{116}$

The clinical implications to VILI from pulmonary capillary stress failure remain unclear. Vasoactive medications may have distinct effects on pulmonary blood flow and distribution and thus attenuate or exacerbate VILI. ${ }^{117,118}$ A randomized clinical trial evaluating hemodynamic management for neuroprotection following severe head injury found increased ARDS incidence in the strategy requiring increased vasopressor use and intravenous fluid administration to achieve higher mean arterial and cerebral perfusion pressures. ${ }^{119}$ Similarly, in a multicenter trial of patients with ARDS, a more liberal fluid management strategy was associated with fewer ventilator-free days compared to a strategy favoring earlier diuresis, although survival did not differ significantly between groups. ${ }^{120}$ While capillary stress failure unquestionably plays a role in VILI, the magnitude of its importance and any clinical management decisions that should follow remain to be defined.

\section{VILI PREVENTION IN PATIENTS WITHOUT ARDS}

Perhaps the greatest challenge for VILI prevention, among patients without ARDS, is to balance the degree of VILI risk with the potential for harm from a given VILI prevention strategy. Clinical lung injury does not develop in most patients even when identifiable risk factors are present. ${ }^{121,122}$ Clinical risk prediction scores such as the Lung Injury Prediction 
Score (LIPS) $)^{122}$ and Early Acute Lung Injury Score ${ }^{123}$ perform reasonably well in identifying patients at-risk of lung injury, but have yet to prove useful in guiding preventive strategies. A multiple-hit conceptual model for VILI risk has been proposed, wherein patients with increased baseline risk for lung injury (e.g. from pneumonia or sepsis) are likeliest to develop clinical lung injury if secondary insults are encountered (e.g. exposure to high tidal volumes). ${ }^{124}$

Among candidate interventions for VILI prevention in patients without ARDS, limiting tidal volume has been most widely studied. A two-hospital randomized trial found decreased ARDS incidence with 6 versus $10 \mathrm{~mL} / \mathrm{kg}$ PBW in critically ill non-ARDS patients with anticipated need for mechanical ventilation of more than three days, although survival and ventilator-free days did not differ. ${ }^{125} \mathrm{~A}$ multicenter trial of intraoperative low tidal volumes among high-risk patients undergoing abdominal surgery found decreased need for postoperative positive pressure ventilation and shorter hospital length of stay with 6-8 $\mathrm{mL} / \mathrm{kg}$ PBW compared to $10-12 \mathrm{~mL} / \mathrm{kg}$ PBW. ${ }^{126}$ Building on these findings, a recent metaanalysis of 15 small randomized trials and 5 large observational studies similarly concluded lower tidal volumes targeting 6-8 $\mathrm{mL} / \mathrm{kg}$ PBW were associated with improved survival in patients without ARDS. ${ }^{127}$ However, attempts to restrict tidal volume may prove challenging in patients supported in assist-control or pressure-support modes ${ }^{128,129}$ without increasing sedation or even administering neuromuscular blockade to blunt patient inspiratory effort. Careful evaluation of the costs from such co-interventions must be addressed before broadly recommending low tidal volumes for all. ${ }^{130}$ This balance may be easier to strike for intraoperative low tidal volumes among high-risk patients because general anesthesia and neuromuscular blockade are routine in many major surgeries. Ideally, tidal volume limits might be individualized for each patient according to VILI risk and level of co-interventions (e.g. sedatives, paralytics) required to achieve them.

\section{SUMMARY}

Prevention of VILI can attenuate multiorgan failure and improve survival. Clinically significant VILI may occur from volutrauma, barotrauma, atelectrauma, biotrauma, and shear strain. Differences in regional mechanics play an increasingly recognized role in VILI pathogenesis and prevention. Less well understood are the contributions of alveolar stress frequency and pulmonary capillary stress failure, though both have compelling biological plausibility. Increased understanding of VILI has led to several preventive strategies targeting underlying mechanisms (Table 2). VILI occurs most readily in patients with concomitant physiological insults (e.g. sepsis, trauma, major surgery) that prime the immune system for a cascading response to mechanical lung injury. Because the majority of nonARDS patients at risk of VILI do not develop clinically significant lung injury, ${ }^{121,122}$ prevention efforts should carry minimal side-effects to justify broad application or be targeted to subsets of patients at increased risk.

\section{Acknowledgments}

Funding Sources: All authors have received funding support from the National Institutes of Health. 


\section{REFERENCES}

1. Fothergill J. Observations on a case published in the last volume of the medical essays, \& of recovering a man dead in appearance, by distending the lungs with air. Philosophical Transactions. 1744; 43:275-281.

2. Slutsky AS. History of Mechanical Ventilation. From Vesalius to Ventilator-induced Lung Injury. Am J Respir Crit Care Med. 2015; 191(10):1106-1115. [PubMed: 25844759]

3. Acute Respiratory Distress Syndrome Network. Ventilation with lower tidal volumes as compared with traditional tidal volumes for acute lung injury and the acute respiratory distress syndrome. $\mathrm{N}$ Engl J Med. 2000; 342(18):1301-1308. [PubMed: 10793162]

4. Slutsky AS. Lung injury caused by mechanical ventilation. Chest. 1999; 116(1 Suppl):9S-15S.

5. Amato MB, Barbas CS, Medeiros DM, et al. Effect of a protective-ventilation strategy on mortality in the acute respiratory distress syndrome. N Engl J Med. 1998; 338(6):347-354. [PubMed: 9449727]

6. Dreyfuss D, Soler P, Basset G, Saumon G. High inflation pressure pulmonary edema. Respective effects of high airway pressure, high tidal volume, and positive end-expiratory pressure. Am Rev Respir Dis. 1988; 137(5):1159-1164. [PubMed: 3057957]

7. Hernandez LA, Peevy KJ, Moise AA, Parker JC. Chest wall restriction limits high airway pressureinduced lung injury in young rabbits. J Appl Physiol. 1989; 66(5):2364-2368. [PubMed: 2745302]

8. Carlton DP, Cummings JJ, Scheerer RG, Poulain FR, Bland RD. Lung overexpansion increases pulmonary microvascular protein permeability in young lambs. J Appl Physiol. 1990; 69(2):577583. [PubMed: 2228868]

9. Adkins WK, Hernandez LA, Coker PJ, Buchanan B, Parker JC. Age effects susceptibility to pulmonary barotrauma in rabbits. Crit Care Med. 1991; 19(3):390-393. [PubMed: 1999101]

10. Dreyfuss D, Saumon G. Ventilator-induced lung injury: lessons from experimental studies. Am J Respir Crit Care Med. 1998; 157(1):294-323. [PubMed: 9445314]

11. Mead J, Takishima T, Leith D. Stress distribution in lungs: a model of pulmonary elasticity. J Appl Physiol. 1970; 28(5):596-608. [PubMed: 5442255]

12. Talmor D, Sarge T, O'Donnell CR, et al. Esophageal and transpulmonary pressures in acute respiratory failure. Crit Care Med. 2006; 34(5):1389-1394. [PubMed: 16540960]

13. Slutsky AS, Ranieri VM. Ventilator-induced lung injury. N Engl J Med. 2013; 369(22):2126-2136. [PubMed: 24283226]

14. Pelosi P, Croci M, Ravagnan I, Vicardi P, Gattinoni L. Total respiratory system, lung, and chest wall mechanics in sedated-paralyzed postoperative morbidly obese patients. Chest. 1996; 109(1): 144-151. [PubMed: 8549177]

15. Hibbert K, Rice M, Malhotra A. Obesity and ARDS. Chest. 2012; 142(3):785-790. [PubMed: 22948584]

16. Yoshida T, Uchiyama A, Matsuura N, Mashimo T, Fujino Y. Spontaneous breathing during lungprotective ventilation in an experimental acute lung injury model. Crit Care Med. 2012; 40(5): 1578-1585. [PubMed: 22430241]

17. Tschumperlin DJ, Oswari J, Margulies AS. Deformation-induced injury of alveolar epithelial cells. Effect of frequency, duration, and amplitude. Am J Respir Crit Care Med. 2000; 162(2 Pt 1):357362. [PubMed: 10934053]

18. Ye H, Gao Z, Ren Y, Liu X, Yang C, Wang C. Cyclic deformation-induced injury and differentiation of rat alveolar epithelial type II cells. Respir Physiol Neurobiol. 2012; 180(2-3): 237-246. [PubMed: 22154752]

19. Frank JA, Gutierrez JA, Jones KD, Allen L, Dobbs L, Matthay MA. Low tidal volume reduces epithelial and endothelial injury in acid-injured rat lungs. Am J Respir Crit Care Med. 2002; 165(2):242-249. [PubMed: 11790662]

20. Kolobow T, Moretti MP, Fumagalli R, et al. Severe impairment in lung function induced by high peak airway pressure during mechanical ventilation. An experimental study. Am Rev Respir Dis. 1987; 135(2):312-315. [PubMed: 3544984] 
21. Protti A, Andreis DT, Monti M, et al. Lung stress and strain during mechanical ventilation: any difference between statics and dynamics? Crit Care Med. 2013; 41(4):1046-1055. [PubMed: 23385096]

22. Webb HH, Tierney DF. Experimental pulmonary edema due to intermittent positive pressure ventilation with high inflation pressures. Protection by positive end-expiratory pressure. Am Rev Respir Dis. 1974; 110(5):556-565. [PubMed: 4611290]

23. Tremblay L, Valenza F, Ribeiro SP, Li J, Slutsky AS. Injurious ventilatory strategies increase cytokines and c-fos m-RNA expression in an isolated rat lung model. J Clin Invest. 1997; 99(5): 944-952. [PubMed: 9062352]

24. Loring SH, O'Donnell CR, Behazin N, et al. Esophageal pressures in acute lung injury: do they represent artifact or useful information about transpulmonary pressure, chest wall mechanics, and lung stress? J Appl Physiol. 2010; 108(3):515-522. [PubMed: 20019160]

25. Beitler JR, Majumdar R, Hubmayr RD, et al. Volume delivered during recruitment maneuver predicts lung stress in acute respiratory distress syndrome. Crit Care Med. 2016; 44(1):91-99.

26. Caironi P, Cressoni M, Chiumello D, et al. Lung opening and closing during ventilation of acute respiratory distress syndrome. Am J Respir Crit Care Med. 2010; 181(6):578-586. [PubMed: 19910610]

27. Bachofen H, Schurch S, Urbinelli M, Weibel ER. Relations among alveolar surface tension, surface area, volume, and recoil pressure. J Appl Physiol. 1987; 62(5):1878-1887. [PubMed: 3597262]

28. Mercer RR, Laco JM, Crapo JD. Three-dimensional reconstruction of alveoli in the rat lung for pressure-volume relationships. J Appl Physiol. 1987; 62(4):1480-1487. [PubMed: 3597219]

29. Tschumperlin DJ, Margulies SS. Alveolar epithelial surface area-volume relationship in isolated rat lungs. J Appl Physiol. 1999; 86(6):2026-2033. [PubMed: 10368370]

30. Vlahakis NE, Hubmayr RD. Plasma membrane stress failure in alveolar epithelial cells. J Appl Physiol. 2000; 89(6):2490-2496. [PubMed: 11090606]

31. Vlahakis NE, Schroeder MA, Pagano RE, Hubmayr RD. Deformation-induced lipid trafficking in alveolar epithelial cells. Am J Physiol Lung Cell Mol Physiol. 2001; 280(5):L938-L946. [PubMed: 11290518]

32. Vlahakis NE, Schroeder MA, Pagano RE, Hubmayr RD. Role of deformation-induced lipid trafficking in the prevention of plasma membrane stress failure. Am J Respir Crit Care Med. 2002; 166(9):1282-1289. [PubMed: 12403699]

33. Vlahakis NE, Hubmayr RD. Cellular stress failure in ventilator-injured lungs. Am J Respir Crit Care Med. 2005; 171(12):1328-1342. [PubMed: 15695492]

34. Fu Z, Costello ML, Tsukimoto K, et al. High lung volume increases stress failure in pulmonary capillaries. J Appl Physiol. 1992; 73(1):123-133. [PubMed: 1506359]

35. Pelosi P, D'Andrea L, Vitale G, Pesenti A, Gattinoni L. Vertical gradient of regional lung inflation in adult respiratory distress syndrome. Am J Respir Crit Care Med. 1994; 149(1):8-13. [PubMed: 8111603]

36. Taskar V, John J, Evander E, Robertson B, Jonson B. Surfactant dysfunction makes lungs vulnerable to repetitive collapse and reexpansion. Am J Respir Crit Care Med. 1997; 155(1):313320. [PubMed: 9001330]

37. Muscedere JG, Mullen JB, Gan K, Slutsky AS. Tidal ventilation at low airway pressures can augment lung injury. Am J Respir Crit Care Med. 1994; 149(5):1327-1334. [PubMed: 8173774]

38. Albert RK. The role of ventilation-induced surfactant dysfunction and atelectasis in causing acute respiratory distress syndrome. Am J Respir Crit Care Med. 2012; 185(7):702-708. [PubMed: 22227381]

39. Bilek AM, Dee KC, Gaver DP. Mechanisms of surface-tension-induced epithelial cell damage in a model of pulmonary airway reopening. J Appl Physiol. 2003; 94(2):770-783. [PubMed: 12433851]

40. Ghadiali SN, Gaver DP. Biomechanics of liquid-epithelium interactions in pulmonary airways. Respir Physiol Neurobiol. 2008; 163(1-3):232-243. [PubMed: 18511356]

41. Oeckler RA, Lee W-Y, Park M-G, et al. Determinants of plasma membrane wounding by deforming stress. Am J Physiol Lung Cell Mol Physiol. 2010; 299(6):L826-L833. [PubMed: 20889673] 
42. Malhotra A. Low-tidal-volume ventilation in the acute respiratory distress syndrome. N Engl J Med. 2007; 357(11):1113-1120. [PubMed: 17855672]

43. Meade MO, Cook DJ, Guyatt GH, et al. Ventilation strategy using low tidal volumes, recruitment maneuvers, and high positive end-expiratory pressure for acute lung injury and acute respiratory distress syndrome: a randomized controlled trial. JAMA. 2008; 299(6):637-645. [PubMed: 18270352]

44. National Heart, Lung, and Blood Institute ARDS Clinical Trials Network. Higher versus lower positive end-expiratory pressures in patients with the acute respiratory distress syndrome. $\mathrm{N}$ Engl $\mathbf{J}$ Med. 2004; 351(4):327-336. [PubMed: 15269312]

45. Mercat A, Richard J-CM, Vielle B, et al. Positive end-expiratory pressure setting in adults with acute lung injury and acute respiratory distress syndrome: a randomized controlled trial. JAMA. 2008; 299(6):646-655. [PubMed: 18270353]

46. Talmor D, Sarge T, Malhotra A, et al. Mechanical ventilation guided by esophageal pressure in acute lung injury. N Engl J Med. 2008; 359(20):2095-2104. [PubMed: 19001507]

47. Imai Y, Parodo J, Kajikawa O, et al. Injurious mechanical ventilation and end-organ epithelial cell apoptosis and organ dysfunction in an experimental model of acute respiratory distress syndrome. JAMA. 2003; 289(16):2104-2112. [PubMed: 12709468]

48. Ranieri VM, Suter PM, Tortorella C, et al. Effect of mechanical ventilation on inflammatory mediators in patients with acute respiratory distress syndrome: a randomized controlled trial. JAMA. 1999; 282(1):54-61. [PubMed: 10404912]

49. Chiumello D, Pristine G, Slutsky AS. Mechanical ventilation affects local and systemic cytokines in an animal model of acute respiratory distress syndrome. Am J Respir Crit Care Med. 1999; 160(1):109-116. [PubMed: 10390387]

50. Dolinay T, Kim YS, Howrylak J, et al. Inflammasome-regulated cytokines are critical mediators of acute lung injury. Am J Respir Crit Care Med. 2012; 185(11):1225-1234. [PubMed: 22461369]

51. Agrawal A, Zhuo H, Brady S, et al. Pathogenetic and predictive value of biomarkers in patients with ALI and lower severity of illness: results from two clinical trials. Am J Physiol Lung Cell Mol Physiol. 2012; 303(8):L634-L639. [PubMed: 22865551]

52. Parsons PE, Eisner MD, Thompson BT, et al. Lower tidal volume ventilation and plasma cytokine markers of inflammation in patients with acute lung injury. Crit Care Med. 2005; 33(1):1-6. [PubMed: 15644641]

53. Ranieri VM, Giunta F, Suter PM, Slutsky AS. Mechanical ventilation as a mediator of multisystem organ failure in acute respiratory distress syndrome. JAMA. 2000; 284(1):43-44. [PubMed: 10872010]

54. Slutsky AS. Ventilator-induced lung injury: from barotrauma to biotrauma. Respir Care. 2005; 50(5):646-659. [PubMed: 15912625]

55. Maunder RJ, Shuman WP, McHugh JW, Marglin SI, Butler J. Preservation of normal lung regions in the adult respiratory distress syndrome. Analysis by computed tomography. JAMA. 1986; 255(18):2463-2465. [PubMed: 3701964]

56. Gattinoni L, Mascheroni D, Torresin A, et al. Morphological response to positive end expiratory pressure in acute respiratory failure. Computerized tomography study. Intensive Care Med. 1986; 12(3):137-142. [PubMed: 3525633]

57. Gattinoni L, Caironi P, Pelosi P, Goodman LR. What has computed tomography taught us about the acute respiratory distress syndrome? Am J Respir Crit Care Med. 2001; 164(9):1701-1711. [PubMed: 11719313]

58. Perlman CE, Lederer DJ, Bhattacharya J. Micromechanics of alveolar edema. Am J Respir Cell Mol Biol. 2011; 44(1):34-39. [PubMed: 20118224]

59. Wellman TJ, Winkler T, costa ELV, et al. Effect of local tidal lung strain on inflammation in normal and lipopolysaccharide-exposed sheep*. Crit Care Med. 2014; 42(7):e491-e500. [PubMed: 24758890]

60. Bellani G, Messa C, Guerra L, et al. Lungs of patients with acute respiratory distress syndrome show diffuse inflammation in normally aerated regions: a [18F]-fluoro-2-deoxy-D-glucose PET/CT study. Crit Care Med. 2009; 37(7):2216-2222. [PubMed: 19487931] 
61. Cressoni M, Chiumello D, Chiurazzi C, et al. Lung inhomogeneities, inflation and [18F]2-fluoro-2deoxy-d-glucose uptake rate in acute respiratory distress syndrome. Eur Respir J. 2016; 47:233242. [PubMed: 26493798]

62. Cressoni M, Cadringher P, Chiurazzi C, et al. Lung inhomogeneity in patients with acute respiratory distress syndrome. Am J Respir Crit Care Med. 2014; 189(2):149-158. [PubMed: 24261322]

63. Guerin C, Reignier J, Richard J-C, et al. Prone positioning in severe acute respiratory distress syndrome. N Engl J Med. 2013; 368(23):2159-2168. [PubMed: 23688302]

64. Beitler JR, Guerin C, Ayzac L, et al. PEEP titration during prone positioning for acute respiratory distress syndrome. Crit Care. 2015; 19:436. [PubMed: 26686509]

65. Beitler JR, Shaefi S, Montesi SB, et al. Prone positioning reduces mortality from acute respiratory distress syndrome in the low tidal volume era: a meta-analysis. Intensive Care Med. 2014; 40(3): 332-341. [PubMed: 24435203]

66. Gattinoni L, Taccone P, Carlesso E, Marini JJ. Prone position in acute respiratory distress syndrome. Rationale, indications, and limits. Am J Respir Crit Care Med. 2013; 188(11):12861293. [PubMed: 24134414]

67. Gattinoni L, Pelosi P, Crotti S, Valenza F. Effects of positive end-expiratory pressure on regional distribution of tidal volume and recruitment in adult respiratory distress syndrome. Am J Respir Crit Care Med. 1995; 151(6):1807-1814. [PubMed: 7767524]

68. Malo J, Ali J, Wood LD. How does positive end-expiratory pressure reduce intrapulmonary shunt in canine pulmonary edema? J Appl Physiol. 1984; 57(4):1002-1010. [PubMed: 6389451]

69. Paré PD, Warriner B, Baile EM, Hogg JC. Redistribution of pulmonary extravascular water with positive end-expiratory pressure in canine pulmonary edema. Am Rev Respir Dis. 1983; 127(5): 590-593. [PubMed: 6342480]

70. Fernandez-Mondéjar E, Vazquez Mata G, Cárdenas A, Mansilla A, Cantalejo F, Rivera R. Ventilation with positive end-expiratory pressure reduces extravascular lung water and increases lymphatic flow in hydrostatic pulmonary edema. Crit Care Med. 1996; 24(9):1562-1567. [PubMed: 8797632]

71. Kambara K, Longworth KE, Serikov VB, Staub NC. Effect of interstitial edema on lung lymph flow in goats in the absence of filtration. J Appl Physiol. 1992; 72(3):1142-1148. [PubMed: 1568968]

72. Hedenstierna G, Lattuada M. Lymphatics and lymph in acute lung injury. Curr Opin Crit Care. 2008; 14(1):31-36. [PubMed: 18195623]

73. Briel M, Meade M, Mercat A, et al. Higher vs lower positive end-expiratory pressure in patients with acute lung injury and acute respiratory distress syndrome: systematic review and metaanalysis. JAMA. 2010; 303(9):865-873. [PubMed: 20197533]

74. Young D, Lamb SE, Shah S, et al. High-frequency oscillation for acute respiratory distress syndrome. N Engl J Med. 2013; 368(9):806-813. [PubMed: 23339638]

75. Ferguson ND, Cook DJ, Guyatt GH, et al. High-frequency oscillation in early acute respiratory distress syndrome. N Engl J Med. 2013; 368(9):795-805. [PubMed: 23339639]

76. Papazian L, Forel JM, Gacouin A, et al. Neuromuscular blockers in early acute respiratory distress syndrome. N Engl J Med. 2010; 363(12):1107-1116. [PubMed: 20843245]

77. Villar J, Kacmarek RM, Pérez-Méndez L, Aguirre-Jaime A. A high positive end-expiratory pressure, low tidal volume ventilatory strategy improves outcome in persistent acute respiratory distress syndrome: a randomized, controlled trial. Crit Care Med. 2006; 34(5):1311-1318. [PubMed: 16557151]

78. Suter PM, Fairley B, Isenberg MD. Optimum end-expiratory airway pressure in patients with acute pulmonary failure. N Engl J Med. 1975; 292(6):284-289. [PubMed: 234174]

79. Pintado M-C, de Pablo R, Trascasa M, et al. Individualized PEEP setting in subjects with ARDS: a randomized controlled pilot study. Respir Care. 2013; 58(9):1416-1423. [PubMed: 23362167]

80. Kacmarek RM, Villar J, Sulemanji D, et al. Open lung approach for the acute respiratory distress syndrome: a pilot, randomized controlled trial. Crit Care Med. 2016; 44(1):32-42. [PubMed: 26672923] 
81. Gattinoni L, Pesenti A, Carlesso E. Body position changes redistribute lung computed-tomographic density in patients with acute respiratory failure: impact and clinical fallout through the following 20 years. Intensive Care Med. 2013; 39(11):1909-1915. [PubMed: 24026295]

82. Cornejo RA, Díaz JC, Tobar EA, et al. Effects of prone positioning on lung protection in patients with acute respiratory distress syndrome. Am J Respir Crit Care Med. 2013; 188(4):440-448. [PubMed: 23348974]

83. Gattinoni L, D'Andrea L, Pelosi P, Vitale G, Pesenti A, Fumagalli R. Regional effects and mechanism of positive end-expiratory pressure in early adult respiratory distress syndrome. JAMA. 1993; 269(16):2122-2127. [PubMed: 8468768]

84. Gattinoni L, Pesenti A. The concept of "baby lung". Intensive Care Med. 2005; 31(6):776-784. [PubMed: 15812622]

85. Langer M, Mascheroni D, Marcolin R, Gattinoni L. The prone position in ARDS patients. A clinical study. Chest. 1988; 94(1):103-107. [PubMed: 3383620]

86. Costa E, Musch G, Winkler T, et al. Mild endotoxemia during mechanical ventilation produces spatially heterogeneous pulmonary neutrophilic inflammation in sheep. Anesthesiology. 2010; 112(3):658-669. [PubMed: 20179503]

87. Cereda M, Emami K, Kadlecek S, et al. Quantitative imaging of alveolar recruitment with hyperpolarized gas MRI during mechanical ventilation. J Appl Physiol. 2011; 110(2):499-511. [PubMed: 21127207]

88. Cereda M, Emami K, Xin Y, et al. Imaging the interaction of atelectasis and overdistension in surfactant-depleted lungs. Crit Care Med. 2013; 41(2):527-535. [PubMed: 23263577]

89. Chiumello D, Carlesso E, Cadringher P, et al. Lung stress and strain during mechanical ventilation for acute respiratory distress syndrome. Am J Respir Crit Care Med. 2008; 178(4):346-355. [PubMed: 18451319]

90. Mattingley JS, Holets SR, Oeckler RA, Stroetz RW, Buck CF, Hubmayr RD. Sizing the lung of mechanically ventilated patients. Crit Care. 2011; 15(1):R60. [PubMed: 21320330]

91. Cohen TS, Cavanaugh KJ, Margulies SS. Frequency and peak stretch magnitude affect alveolar epithelial permeability. Eur Respir J. 2008; 32(4):854-861. [PubMed: 18614557]

92. Hotchkiss JR, Blanch L, Murias G, et al. Effects of decreased respiratory frequency on ventilatorinduced lung injury. Am J Respir Crit Care Med. 2000; 161:463-468. [PubMed: 10673186]

93. Vaporidi K, Voloudakis G, Priniannakis G, et al. Effects of respiratory rate on ventilator-induced lung injury at a constant $\mathrm{PaCO} 2$ in a mouse model of normal lung. Crit Care Med. 2008; 36(4): 1277-1283. [PubMed: 18379255]

94. Brower RG, Morris A, MacIntyre N, et al. Effects of recruitment maneuvers in patients with acute lung injury and acute respiratory distress syndrome ventilated with high positive end-expiratory pressure. Crit Care Med. 2003; 31(11):2592-2597. [PubMed: 14605529]

95. Jabaudon M, Hamroun N, Roszyk L, et al. Effects of a recruitment maneuver on plasma levels of soluble RAGE in patients with diffuse acute respiratory distress syndrome: a prospective randomized crossover study. Intensive Care Med. 2015; 41(5):846-855. [PubMed: 25792206]

96. Pelosi P, Bottino N, Chiumello D, et al. Sigh in supine and prone position during acute respiratory distress syndrome. Am J Respir Crit Care Med. 2003; 167(4):521-527. [PubMed: 12493644]

97. Mauri T, Eronia N, Abbruzzese C, et al. Effects of sigh on regional lung strain and ventilation heterogeneity in acute respiratory failure patients undergoing assisted mechanical ventilation. Crit Care Med. 2015; 43(9):1823-1831. [PubMed: 25985386]

98. Steimback PW, Oliveira GP, Rzezinski AF, et al. Effects of frequency and inspiratory plateau pressure during recruitment manoeuvres on lung and distal organs in acute lung injury. Intensive Care Med. 2009; 35(6):1120-1128. [PubMed: 19221714]

99. Hickling KG, Henderson SJ, Jackson R. Low mortality associated with low volume pressure limited ventilation with permissive hypercapnia in severe adult respiratory distress syndrome. Intensive Care Med. 1990; 16(6):372-377. [PubMed: 2246418]

100. O'Toole D, Hassett P, Contreras M, et al. Hypercapnic acidosis attenuates pulmonary epithelial wound repair by an NF-kappaB dependent mechanism. Thorax. 2009; 64(11):976-982.

[PubMed: 19617214] 
101. Caples SM, Rasmussen DL, Lee WY, Wolfert MZ, Hubmayr RD. Impact of buffering hypercapnic acidosis on cell wounding in ventilator-injured rat lungs. Am J Physiol Lung Cell Mol Physiol. 2009; 296(1):L140-L144. [PubMed: 18996901]

102. Briva A, Vadász I, Lecuona E, et al. High CO2 levels impair alveolar epithelial function independently of pH. PLoS ONE. 2007; 2(11):e1238. [PubMed: 18043745]

103. Shibata K, Cregg N, Engelberts D, Takeuchi A, Fedorko L, Kavanagh BP. Hypercapnic acidosis may attenuate acute lung injury by inhibition of endogenous xanthine oxidase. Am J Respir Crit Care Med. 1998; 158(5):1578-1584. [PubMed: 9817711]

104. Takeshita K, Suzuki Y, Nishio K, et al. Hypercapnic acidosis attenuates endotoxin-induced nuclear factor-[kappa]B activation. Am J Respir Cell Mol Biol. 2003; 29(1):124-132. [PubMed: 12600832]

105. West MA, Baker J, Bellingham J. Kinetics of decreased LPS-stimulated cytokine release by macrophages exposed to CO2. J Surg Res. 1996; 63(1):269-274. [PubMed: 8661209]

106. Coakley RJ, Taggart C, Greene C, McElvaney NG, O'Neill SJ. Ambient pCO2 modulates intracellular $\mathrm{pH}$, intracellular oxidant generation, and interleukin-8 secretion in human neutrophils. J Leukoc Biol. 2002; 71(4):603-610. [PubMed: 11927646]

107. Wang N, Gates KL, Trejo H, et al. Elevated CO2 selectively inhibits interleukin-6 and tumor necrosis factor expression and decreases phagocytosis in the macrophage. FASEB J. 2010; 24(7): 2178-2190. [PubMed: 20181940]

108. Contreras M, Ansari B, Curley G, et al. Hypercapnic acidosis attenuates ventilation-induced lung injury by a nuclear factor- $\kappa B$-dependent mechanism. Crit Care. 2012; 40(9):2622-2630.

109. Sinclair SE, Kregenow DA, Lamm WJE, Starr IR, Chi EY, Hlastala MP. Hypercapnic acidosis is protective in an in vivo model of ventilator-induced lung injury. Am J Respir Crit Care Med. 2002; 166(3):403-408. [PubMed: 12153979]

110. Chonghaile MN, Higgins BD, Costello J, Laffey JG. Hypercapnic acidosis attenuates lung injury induced by established bacterial pneumonia. Anesthesiology. 2008; 109(5):837-848. [PubMed: 18946296]

111. Costello J, Higgins B, Contreras M, et al. Hypercapnic acidosis attenuates shock and lung injury in early and prolonged systemic sepsis. Crit Care Med. 2009; 37(8):2412-2420. [PubMed: 19531945]

112. O'Croinin DF, Nichol AD, Hopkins N, et al. Sustained hypercapnic acidosis during pulmonary infection increases bacterial load and worsens lung injury. Crit Care Med. 2008; 36(7):21282135. [PubMed: 18552698]

113. West JB, Tsukimoto K, Mathieu-Costello O, Prediletto R. Stress failure in pulmonary capillaries. J Appl Physiol. 1991; 70(4):1731-1742. [PubMed: 2055852]

114. Broccard AF, Hotchkiss JR, Kuwayama N, et al. Consequences of vascular flow on lung injury induced by mechanical ventilation. Am J Respir Crit Care Med. 1998; 157(6):1935-1942. [PubMed: 9620930]

115. López-Aguilar J, Piacentini E, Villagrá A, et al. Contributions of vascular flow and pulmonary capillary pressure to ventilator-induced lung injury. Crit Care Med. 2006; 34(4):1106-1112. [PubMed: 16484897]

116. Guery BP, deBoisblanc BP, Fialdes P, et al. Pulmonary stress injury within physiological ranges of airway and vascular pressures. J Crit Care. 1998; 13(2):58-66. [PubMed: 9627272]

117. Dreyfuss D, Saumon G. Role of tidal volume, FRC, and end-inspiratory volume in the development of pulmonary edema following mechanical ventilation. Am Rev Respir Dis. 1993; 148(5):1194-1203. [PubMed: 8239153]

118. Briot R, Bayat S, Anglade D, Martiel J-L, Grimbert F. Increased cardiac index due to terbutaline treatment aggravates capillary-alveolar macromolecular leakage in oleic acid lung injury in dogs. Crit Care. 2009; 13(5):R166. [PubMed: 19845949]

119. Robertson CS, Valadka AB, Hannay HJ, et al. Prevention of secondary ischemic insults after severe head injury. Crit Care Med. 1999; 27(10):2086-2095. [PubMed: 10548187]

120. National Heart, Lung, and Blood Institute ARDS Clinical Trials Network. Comparison of two fluid-management strategies in acute lung injury. N Engl J Med. 2006; 354(24):2564-2575. [PubMed: 16714767] 
121. Ferguson ND, Frutos-Vivar F, Esteban A, et al. Clinical risk conditions for acute lung injury in the intensive care unit and hospital ward: a prospective observational study. Crit Care. 2007; 11(5):R96. [PubMed: 17784960]

122. Gajic O, Dabbagh O, Park PK, et al. Early identification of patients at risk of acute lung injury: evaluation of lung injury prediction score in a multicenter cohort study. Am J Respir Crit Care Med. 2011; 183(4):462-470. [PubMed: 20802164]

123. Levitt JE, Calfee CS, Goldstein BA, Vojnik R, Matthay MA. Early acute lung injury: criteria for identifying lung injury prior to the need for positive pressure ventilation. Crit Care Med. 2013; 41(8):1929-1937. [PubMed: 23782966]

124. Litell JM, Gong MN, Talmor D, Gajic O. Acute lung injury: prevention may be the best medicine. Respir Care. 2011; 56(10):1546-1554. [PubMed: 22008396]

125. Determann RM, Royakkers A, Wolthuis EK, et al. Ventilation with lower tidal volumes as compared with conventional tidal volumes for patients without acute lung injury: a preventive randomized controlled trial. Crit Care. 2010; 14(1):R1. [PubMed: 20055989]

126. Futier E, Constantin JM, Paugam-Burtz C, et al. A trial of intraoperative low-tidal-volume ventilation in abdominal surgery. N Engl J Med. 2013; 369(5):428-437. [PubMed: 23902482]

127. Serpa Neto A, Cardoso SO, Manetta JA, et al. Association between use of lung-protective ventilation with lower tidal volumes and clinical outcomes among patients without acute respiratory distress syndrome: a meta-analysis. JAMA. 2012; 308(16):1651-1659. [PubMed: 23093163]

128. Pohlman MC, McCallister KE, Schweickert WD, et al. Excessive tidal volume from breath stacking during lung-protective ventilation for acute lung injury. Crit Care Med. 2008; 36(11): 3019-3023. [PubMed: 18824913]

129. Chanques G, Kress JP, Pohlman A, et al. Impact of ventilator adjustment and sedation-analgesia practices on severe asynchrony in patients ventilated in assist-control mode. Crit Care Med. 2013; 41(9):2177-2187. [PubMed: 23782972]

130. Ferguson ND. Low tidal volumes for all? JAMA. 2012; 308(16):1689-1690. [PubMed: 23093167]

131. Amato MBP, Meade MO, Slutsky AS, et al. Driving pressure and survival in acute respiratory distress syndrome. N Engl J Med. 2015; 372(8):747-755. [PubMed: 25693014] 


\section{SYNOPSIS}

Prevention of ventilator-induced lung injury (VILI) can attenuate multiorgan failure and improve survival in at-risk patients. Clinically significant VILI occurs from volutrauma, barotrauma, atelectrauma, biotrauma, and shear strain. Differences in regional mechanics play an increasingly recognized role in VILI pathogenesis. Several interventions targeting these mechanisms are available to protect against VILI. However, most patients at risk of lung injury do not develop VILI. Current evidence supports the multiple-hit hypothesis, which states that VILI occurs most readily in patients with concomitant physiological insults (e.g. sepsis, trauma, major surgery) that prime the immune system for a cascading response to mechanical lung injury. VILI prevention strategies must balance risk of lung injury with untoward side-effects from the preventive effort, and may be most effective when targeted to subsets of patients at increased risk. 


\section{KEY POINTS}

- $\quad$ Prevention of ventilator-induced lung injury (VILI) can attenuate multiorgan failure and improve survival in at-risk patients.

- $\quad$ Clinically significant VILI occurs from volutrauma, barotrauma, atelectrauma, biotrauma, and shear strain. Differences in regional mechanics play an increasingly recognized role in VILI pathogenesis.

- $\quad$ VILI occurs most readily in patients with concomitant physiological insults (e.g. sepsis, trauma, major surgery) that prime the immune system for a cascading response to mechanical lung injury.

VILI prevention strategies must balance risk of lung injury with untoward side-effects from the preventive effort, and may be most effective when targeted to subsets of patients at increased risk. 
A

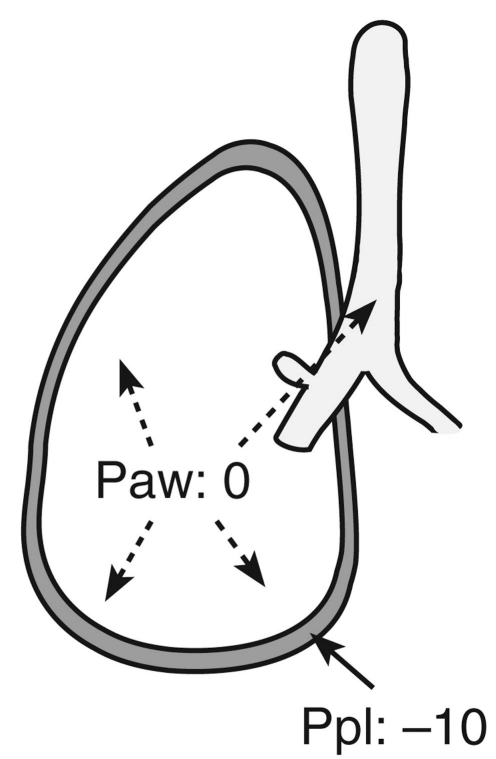

Ptp $=0-(-10)=+10 \mathrm{cmH}_{2} \mathrm{O}$

C

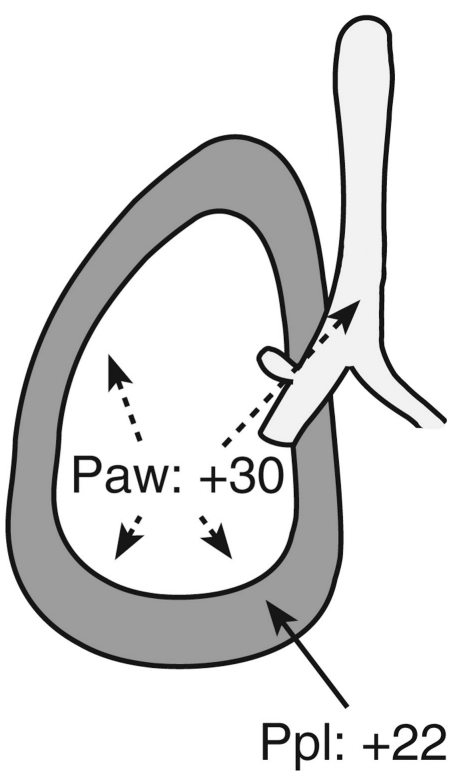

Ptp $=+30-(+22)=+8 \mathrm{cmH}_{2} \mathrm{O}$
B

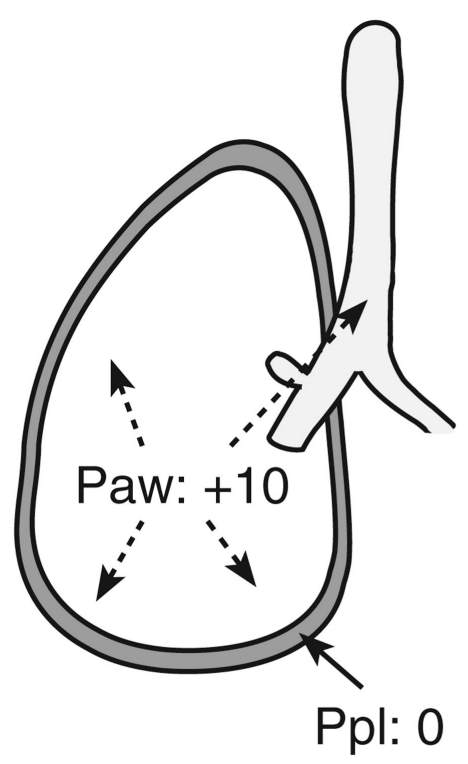

Ptp $=+10-(0)=+10 \mathrm{cmH}_{2} \mathrm{O}$

D

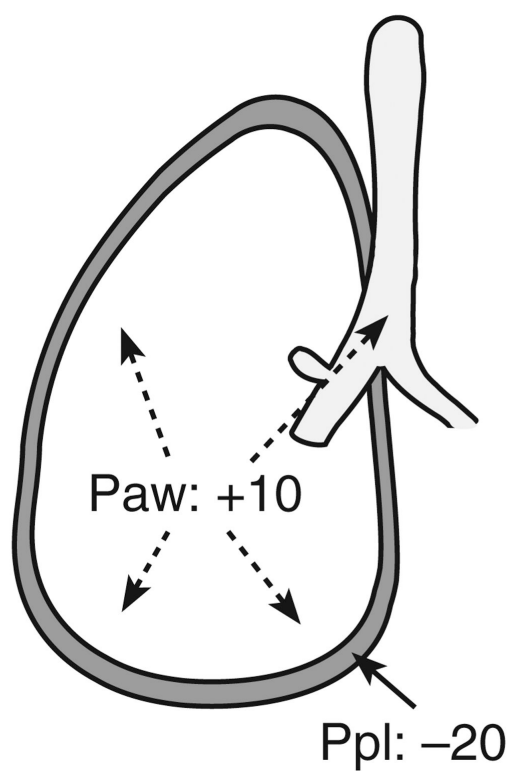

Ptp $=+10-(-20)=+30 \mathrm{cmH}_{2} \mathrm{O}$

Figure 1. Transpulmonary pressure

Transpulmonary pressure $\left(\mathrm{P}_{\text {airway }}-\mathrm{P}_{\text {pleural }}\right)$ is the pertinent distending pressure of the lung. At zero flow, airway and alveolar pressure are equal, for example during an end-inspiratory plateau pressure maneuver. (a) Non-intubated patient, normal spontaneous breathing at endinspiration. (b) Intubated patient without respiratory disease, passive on mechanical ventilator at end-inspiration. (c) Intubated patient, chest wall stiffness results in lower transpulmonary pressure and lower lung volume at end-inspiration despite higher airway pressure. (d) Intubated patient, forceful inspiratory muscle effort, such as from heightened 
respiratory drive, produces high transpulmonary pressure and lung volume at endinspiration even though airway pressure is reasonably low. Abbreviations: Paw, airway pressure; Ppl, pleural pressure; Ptp, transpulmonary pressure.

Adapted from Slutsky AS, Ranieri VM. Ventilator-induced lung injury. N Engl J Med 2013;369(22):2126-36; with permission. 
A.

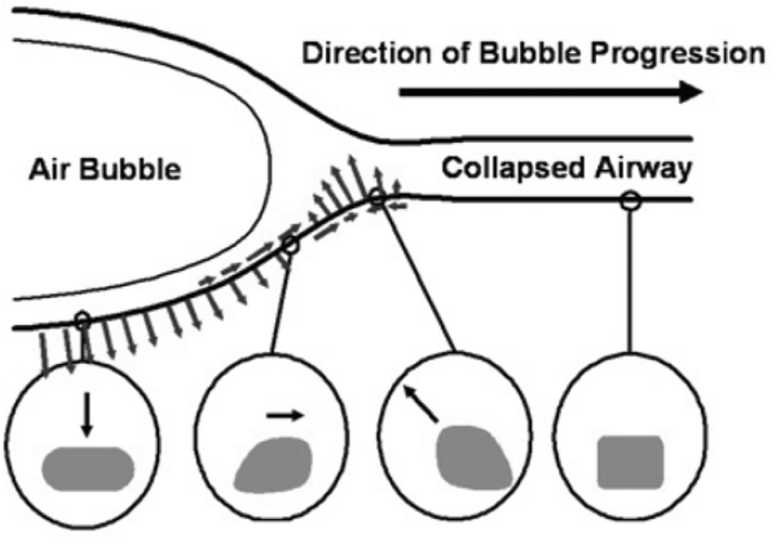

B.

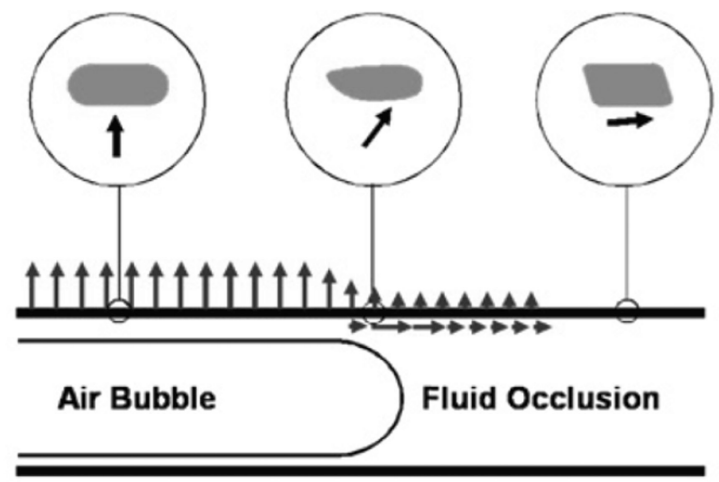

Direction of Bubble Progression

Figure 2. Atelectrauma

Local stress and strain of epithelial cells generated during alveolar recruitment. (a) Air bubble propagation down atelectatic airway generates dynamic wave of shear stress and strain at interface of air bubble and collapsed airway. As the air bubble approaches, the epithelial cell is pulled inward toward the bubble. As the air bubble passes, the cell is pushed outward. (b) Air bubble generates similar shear stress and strain of epithelial cells during propagation along flooded airway.

From Ghadiali SN, Gaver DP. Biomechanics of liquid-epithelium interactions in pulmonary airways. Respir Physiol Neurobiol 2008;163(1-3):232-43; with permission. 


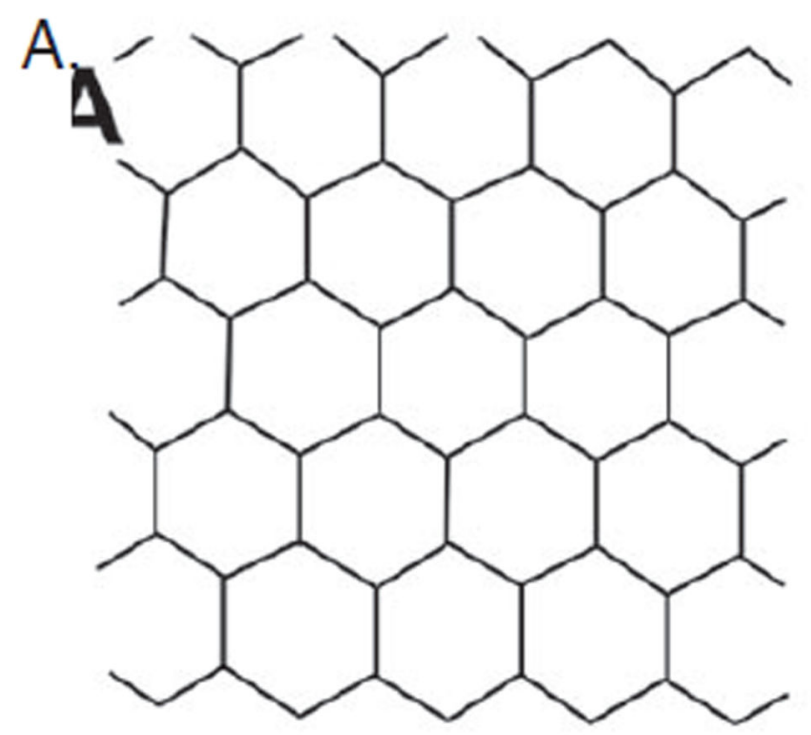

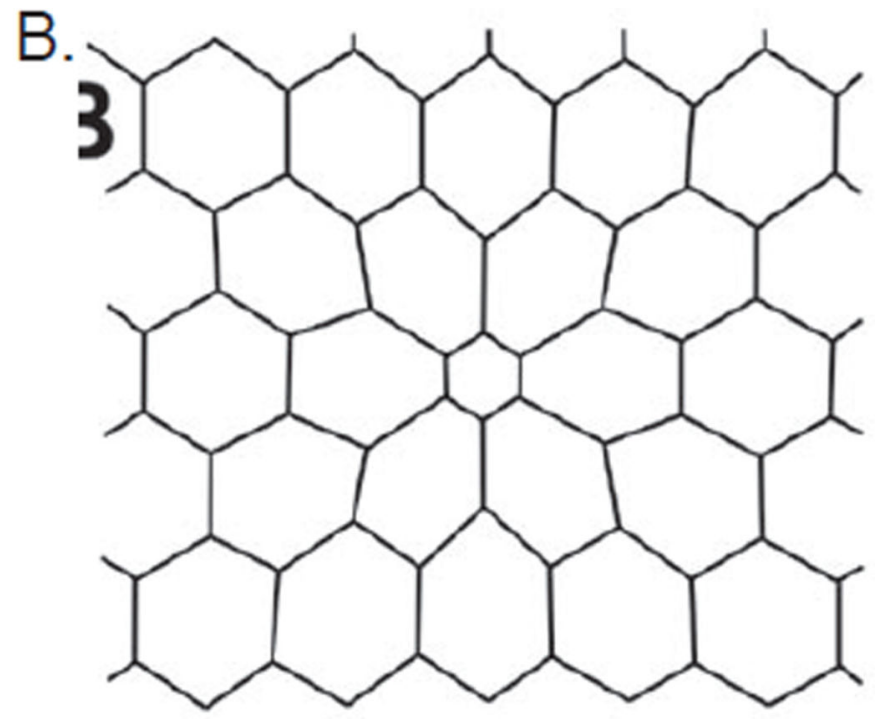
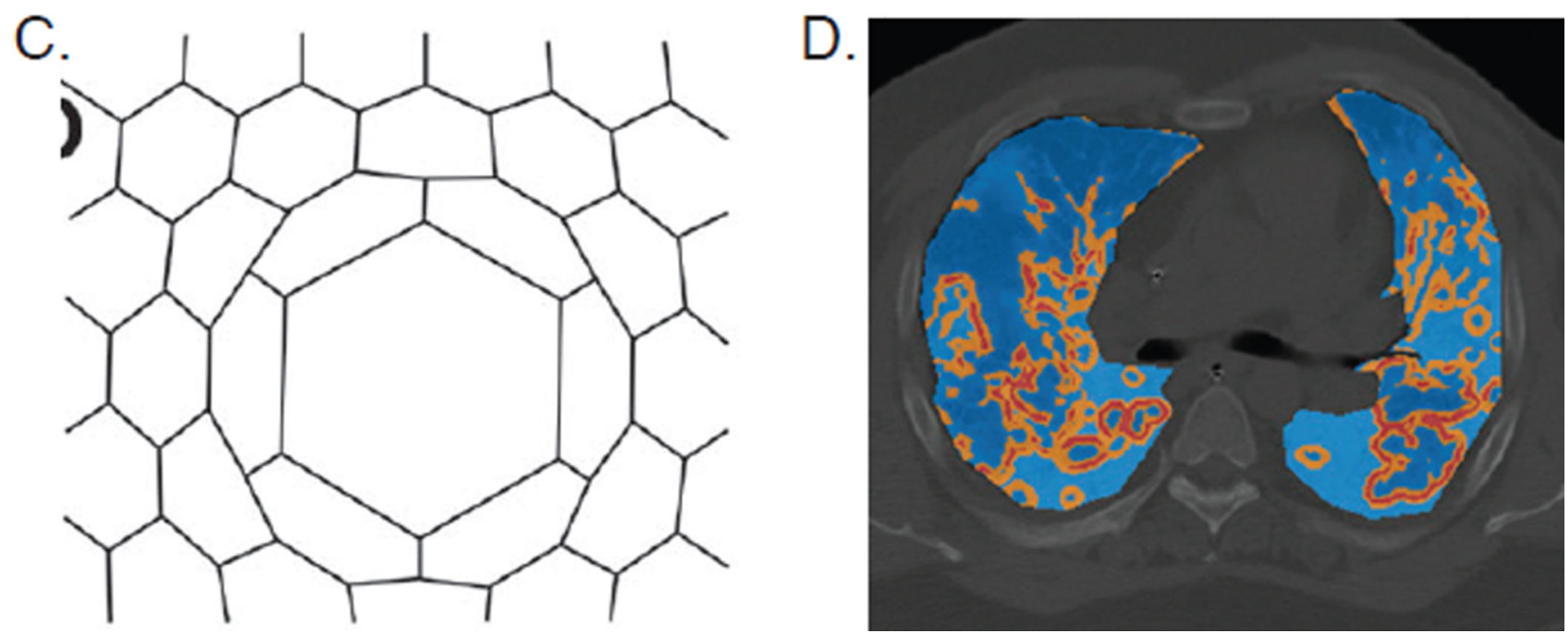

Figure 3. Mechanical alveolar interdependence and shear strain

A-C: classic model of alveolar interdependence; each hexagon represents an alveolus in cross-section. (a) Homogeneous alveolar inflation minimizes strain. (b) Atelectasis of center alveolus induces shear strain of neighboring alveoli. (c) Asymmetric inflation of center alveolus induces shear strain of neighboring alveoli. (d) CT chest with overlying map of CTderived regional stress concentration due to parenchymal heterogeneity in a representative patient with ARDS (light blue: low stress; orange: moderate stress; red: high stress).

Figure 3A-3C from Mead J, Takishima T, Leith D. Stress distribution in lungs: a model of pulmonary elasticity. J Appl Physiol 1970;28(5):596-608. Reprinted with permission of the American Physiological Society; copyright @ 2016 American Physiological Society. Figure 3D from Cressoni M, Cadringher P, Chiurazzi C, et al. Lung inhomogeneity in patients with acute respiratory distress syndrome. Am J Respir Crit Care Med 2014;189(2):149-58. 
Reprinted with permission of the American Thoracic Society; copyright (C) 2016 American Thoracic Society. 


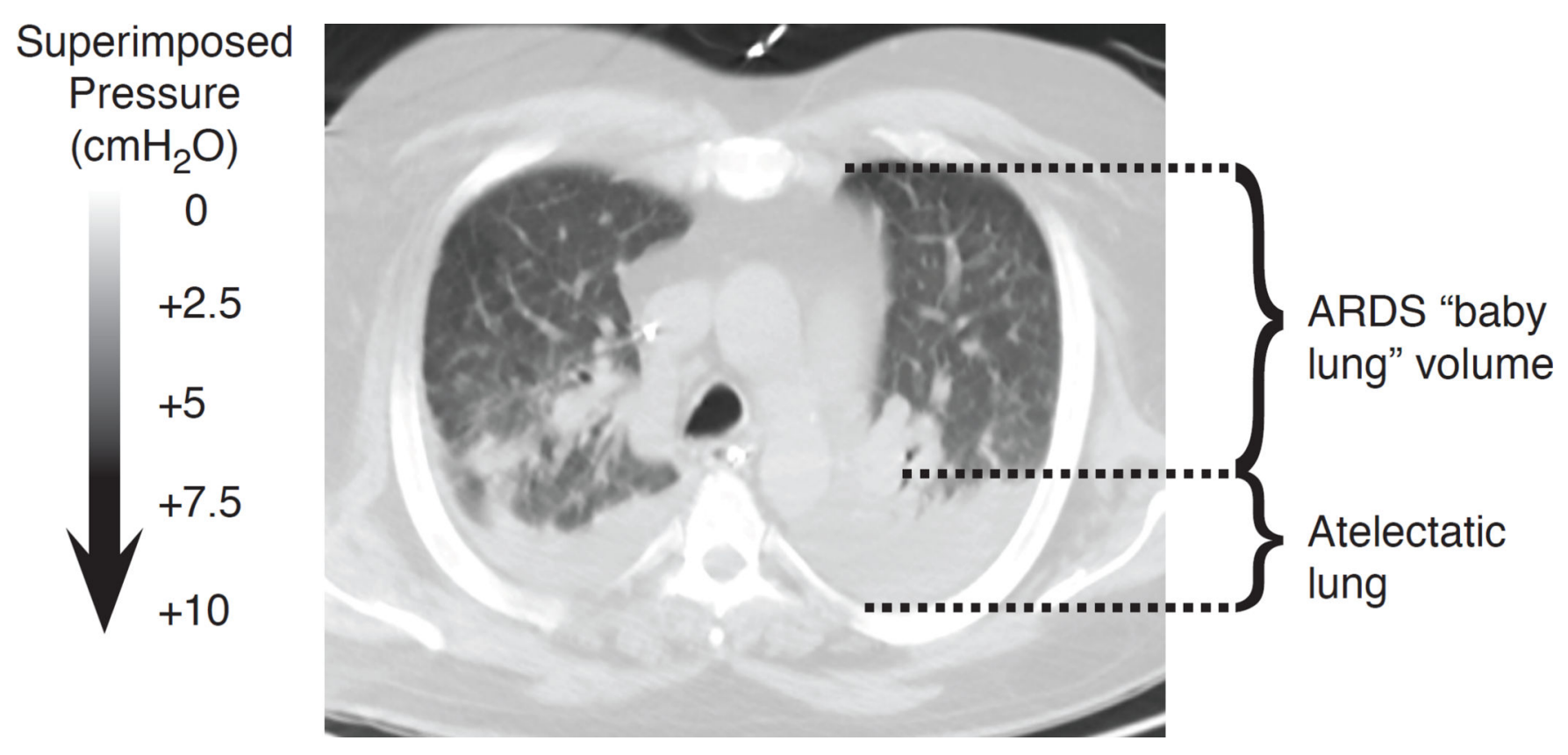

Figure 4. ARDS baby lung

CT chest of representative patient with ARDS. Ventral regions are well-aerated with patchy ground-glass opacities and few areas of focal consolidation from pneumonia. Dorsal regions exhibit dense dependent atelectasis due to superimposed pressure from gravity on the edematous ARDS lung above. As a result, the volume of aerated lung available for gas exchange and mechanical insufflation is reduced—-termed the "baby lung." 


\section{Table 1}

\section{Definitions of Key Terms Frequently Encountered in Literature}

\begin{tabular}{|c|c|}
\hline Term & Definition \\
\hline Atelectrauma & $\begin{array}{l}\text { Lung injury caused by high shear forces from cyclic opening and } \\
\text { collapse of atelectatic but recruitable lung units. }\end{array}$ \\
\hline Baby lung & $\begin{array}{l}\text { Conceptual model for the reduced volume of non-atelectatic } \\
\text { aerated lung available for tidal insufflation and gas exchange in } \\
\text { patients with ARDS. }\end{array}$ \\
\hline Barotrauma & $\begin{array}{l}\text { Lung injury caused by high transpulmonary pressure. May occur } \\
\text { even at lower airway pressure if pleural pressure is extremely } \\
\text { negative (e.g. forceful inspiratory effort). }\end{array}$ \\
\hline Biotrauma & $\begin{array}{l}\text { Additional lung and extra-pulmonary organ injury caused by pro- } \\
\text { injurious inflammatory response to mechanical lung injury. }\end{array}$ \\
\hline Compliance & $\begin{array}{l}\text { Change in volume for a given change in pressure. May refer to } \\
\text { respiratory system compliance }\left(\Delta \mathrm{V} / \Delta \mathrm{P}_{\text {airway }}\right) \text {, lung compliance } \\
\left(\Delta \mathrm{V} / \Delta \mathrm{P}_{\text {transpulmonary }}\right) \text {, or chest wall compliance }\left(\Delta \mathrm{V} / \Delta \mathrm{P}_{\text {pleural }}\right) \text {. } \\
\text { Respiratory system compliance reflects contributions of both the } \\
\text { lung and chest wall, and is often incorrectly labeled as lung } \\
\text { compliance in the literature. }\end{array}$ \\
\hline Elastance & $\begin{array}{l}\text { Change in pressure for a given change in volume, also called } \\
\text { stiffness. Inverse of compliance. }\end{array}$ \\
\hline Lung inhomogeneity & $\begin{array}{l}\text { Differences in regional lung mechanics owing to mechanically } \\
\text { interdependent interalveolar septae shared between aerated } \\
\text { alveoli and adjacent fluid-filled or atelectatic alveoli. Results in } \\
\text { high regional shear strain. Manifested on CT scan as regions of } \\
\text { well-aerated lung adjacent to patchy ground-glass opacities and } \\
\text { atelectasis. }\end{array}$ \\
\hline Shear strain & $\begin{array}{l}\text { Angular deformation of an object relative to its resting } \\
\text { conformation. As example, if resting object is square-shaped, } \\
\text { shear strain would produce an oblique-angled rhombus. }\end{array}$ \\
\hline Strain & $\begin{array}{l}\text { Change in size/shape of an object relative to its resting size/shape, } \\
\text { expressed as ratio of displacement magnitude divided by } \\
\text { reference size. Calculation of lung strain in the mechanically } \\
\text { ventilated patient is controversial because ideal resting size/shape } \\
\text { of the diseased lung is unclear. }\end{array}$ \\
\hline Stress & $\begin{array}{l}\text { Internal forces per unit area that balance an external load. Lung } \\
\text { stress is represented by the transpulmonary pressure. }\end{array}$ \\
\hline Transpulmonary pressure & $\begin{array}{l}\text { Pressure difference inside versus outside the lung }\left(\mathrm{P}_{\mathrm{TP}}=\mathrm{P}_{\text {airway }}-\mathrm{P}_{\text {pleural }}\right) \text {, which is the pertinent distending } \\
\text { pressure of the lung. } \\
\text { Airway and alveolar pressure are equal at points of zero-flow. }\end{array}$ \\
\hline Volutrauma & Lung injury caused by alveolar overdistension. \\
\hline
\end{tabular}


Table 2

Strategies for VILI Prevention in At-Risk Patients

\begin{tabular}{|c|c|c|c|}
\hline $\begin{array}{l}\text { Preventive } \\
\text { Strategy }\end{array}$ & Implementation & VILI Mechanisms* & \\
\hline \multirow[t]{3}{*}{ Limit tidal volume } & \multirow[t]{3}{*}{$\begin{array}{l}\text { Scaled to healthy lung size } \mathrm{e}^{3,5,42} \text { ( } \leq 8 \mathrm{~mL} / \mathrm{kg} \\
\text { PBW) or functional lung size. } .^{25,89} \mathrm{Scaling} \\
\text { to functional lung size may be ideal, but } \\
\text { strategy not yet well defined. }\end{array}$} & $\bullet$ & $\begin{array}{l}\text { Prevent tidal overdistension (volutrauma) } \\
\text { Decrease cyclic and end-inspiratory stress } \\
\text { (barotrauma) }\end{array}$ \\
\hline & & - & $\begin{array}{l}\text { Minimize shear forces via smaller-volume } \\
\text { inflation of aerated alveoli adjacent to } \\
\text { flooded/atelectatic alveoli }\end{array}$ \\
\hline & & - & $\begin{array}{l}\text { Prevent tidal recruitment of atelectatic } \\
\text { alveoli (atelectrauma) }\end{array}$ \\
\hline Limit inspiratory pressure & $\begin{array}{l}\text { Limit airway plateau pressure, }{ }^{3} \text { airway } \\
\text { driving pressure }, 5,131 \text { or transpulmonary } \\
\text { driving pressure. }{ }^{25,46,89} \text { Limiting } \\
\text { transpulmonary driving pressure may be } \\
\text { ideal, but strategy not yet well defined. }\end{array}$ & - & $\begin{array}{l}\text { Identical mechanisms as with limiting } \\
\text { tidal volume }\end{array}$ \\
\hline \multirow[t]{4}{*}{ PEEP } & \multirow{4}{*}{$\begin{array}{l}\text { PEEP-FiO }{ }_{2} \text { table, }{ }^{43,44} \text { maximal static stress } \\
\text { (Express), }{ }^{45} \text { esophageal pressure-guided, }{ }^{46} \\
\text { highest respiratory system compliance, }{ }^{79} \\
\text { lower inflection point of pressure-volume } \\
{\text { curve. }{ }^{5} \text { Mechanics-based approach to }}^{\text {PEEP may be ideal, but optimal strategy }} \\
\text { not yet well defined. }\end{array}$} & - & $\begin{array}{l}\text { Increase aerated functional lung size to } \\
\text { prevent tidal overdistension (volutrauma) }\end{array}$ \\
\hline & & • & $\begin{array}{l}\text { Maintain transpulmonary pressure higher } \\
\text { than closing pressure to prevent tidal } \\
\text { collapse during expiration (atelectrauma) }\end{array}$ \\
\hline & & $\bullet$ & $\begin{array}{l}\text { Improve lung homogeneity to decrease } \\
\text { shear strain }\end{array}$ \\
\hline & & $\bullet$ & $\begin{array}{l}\text { Decrease pulmonary blood flow to } \\
\text { attenuate capillary stress failure }\end{array}$ \\
\hline \multirow[t]{2}{*}{ Prone positioning } & \multirow{2}{*}{$\begin{array}{l}\text { In severe ARDS, prone at least } 16 \text { hours } \\
\text { daily. }{ }^{63} \text { No clinical data to suggest efficacy } \\
\text { as rescue therapy. }\end{array}$} & $\bullet$ & $\begin{array}{l}\text { Improve lung homogeneity to decrease } \\
\text { shear strain }\end{array}$ \\
\hline & & - & $\begin{array}{l}\text { Increase aerated ARDS baby lung size } \\
\text { (volutrauma) }\end{array}$ \\
\hline \multirow[t]{2}{*}{ Limit respiratory rate } & \multirow{2}{*}{$\begin{array}{l}\text { Adjust to maintain minimum allowable } \mathrm{pH} \\
\text { or maximum allowable } \mathrm{PaCO}_{2} \cdot{ }^{5} \text { May } \\
\text { require deep sedation, neuromuscular } \\
\text { blockade, or extracorporeal } \mathrm{CO}_{2} \text { removal. } \\
\text { Not proven in clinical trial vs. high-rate } \\
\text { strategy. }\end{array}$} & $\bullet$ & $\begin{array}{l}\text { Limit stress frequency, reducing exposure } \\
\text { to volutrauma, barotrauma, atelectrauma, } \\
\text { and cyclic strain }\end{array}$ \\
\hline & & $\bullet$ & $\begin{array}{l}\text { Unclear net effect of resultant } \\
\text { hypercapnia }\end{array}$ \\
\hline \multirow[t]{2}{*}{$\begin{array}{l}\text { Limit spontaneous } \\
\text { respiratory effort }\end{array}$} & \multirow[t]{2}{*}{$\begin{array}{l}\text { In severe ARDS, increased sedation } \pm \\
\text { neuromuscular blockade. }^{76}\end{array}$} & $\bullet$ & $\begin{array}{l}\text { Limit inspiratory effort to prevent occult } \\
\text { high tidal volumes from breath stacking }\end{array}$ \\
\hline & & $\bullet$ & $\begin{array}{l}\text { Limit forced expiration to prevent cyclic } \\
\text { derecruitment (atelectrauma) }\end{array}$ \\
\hline
\end{tabular}

Clin Chest Med. Author manuscript; available in PMC 2017 December 01. 